\title{
Retinoblastoma with significant intravitreal haemorrhage: a rare presentation
}

\author{
Rinkey Chaudhary, ${ }^{1}$ Tapendra Tiwari, ${ }^{1}$ Rajaram Sharma 지 , ${ }^{1,2}$ Saurabh Goyal ${ }^{1}$
}

${ }^{1}$ Department of RadioDiagnosis, Pacific Institute of Medical Sciences, Udaipur, Rajasthan, India

${ }^{2}$ Department of Radio-Diagnosis, Seth GS Medical College and KEM Hospital, Mumbai, India

\section{Correspondence to}

Dr Rajaram Sharma:

hemantgalaria13@gmail.com

Accepted 7 September 2021

Check for updates

(c) BMJ Publishing Group Limited 2021. No commercial re-use. See rights and permissions. Published by BMJ.

To cite: Chaudhary $R$, Tiwari T, Sharma R, et al. BMJ Case Rep 2021;14:e246288. doi:10.1136/bcr-2021-

246288

\section{DESCRIPTION}

Retinoblastoma is the most common intraocular tumour of the eye in children. It constitutes $11 \%$ of all cancers within the first year of life. In one-third of cases, it occurs bilaterally; usually, before 5 years of age without any gender predilection. ${ }^{12}$ Trilateral retinoblastoma term is used for unilateral or bilateral presence associated with intracranial tumours of the pineal gland. ${ }^{3-5}$ Retinoblastoma can be hereditary or sporadic-two-thirds of patients present with sporadic mutation of the RB1 gene; located on the long arm of chromosome 13 (13q14). Retinoblastoma is classified as primitive neuroepithelial neoplasm, which arises from the neural epithelium that is typically programmed to evolves into retinal photoreceptor cells. ${ }^{6}$ The primary sign of retinoblastoma is a white pupillary reflex (leukokoria) which is a white or cloudy and dilated pupil. The pupil may look white at certain angles or red in a photo that uses a flashlight, however mostly, the pupils are of similar sizes. Other presentations include crossed eyes (strabismus), eyes may appear misaligned, ranging from mild to severe. Inflammation and irritation can occur anywhere in the eye resulting in redness of the eye. The child can also present with decreased vision (bilateral), retinal detachment, glaucoma, hypopyon or ocular pain.

The primary imaging investigations for retinoblastoma are CT and MRI. CT helps us identify intralesional calcification. MRI is more valuable in retinoblastoma to detect the extension via the optic nerve, leptomeningeal involvement and metastasis in the brain parenchyma. ${ }^{7}$ The tumour may disseminate in the subarachnoid space via the optic nerve.

The mainstay treatment for retinoblastoma is enucleation, but nowadays, conservative management such as cryoablation, photocoagulation and chemotherapy are also recognized for smaller lesions.

Intraocular retinoblastoma has a better prognosis than extraocular or metastatic retinoblastoma. Rarely, spontaneous regression with resultant cure and shrinkage of the eyeball may occur due to necrosis followed by calcification. Prognosis is fair (survival rate 70\%-85\%) if the eyeball is enucleated before the occurrence of extraocular extension.

A 2-year-old girl came to the outpatient department with a 1-week history of left eye pain, redness, vision loss and headache. Her physical examination revealed mild erythema around the left periorbital tissues. The patient had no history of any ocular injury, significant medical history or positive family history. Ophthalmic examination revealed an impaired visual acuity of only hand motion detection in the left eye. Slit-lamp examination

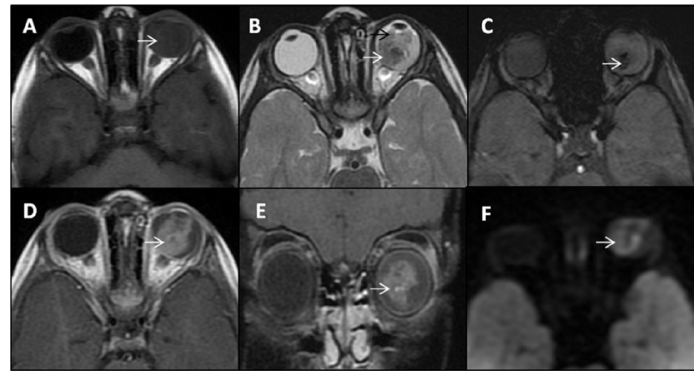

Figure 1 MRI orbit. (A) Unenhanced T1W image in axial plane demonstrates increased signals in the posterior chamber of left eye globe compared with normal hypointense signals in the right eye globe (white arrow). (B) T2W image image in axial plane shows fluid-fluid levelling due to intravitreal haemorrhage (black arrow) in the posterior chamber of left eye globe with internal heterointense lesion attached to the posterior part of the globe (white arrow). (C) Susceptibility-weighted image in axial plane depicts blooming artefact in the lesion suggestive of calcification (white arrow). (D, E) Contrastenhanced T1W images images in axial and coronal plane demonstrate heterogeneously enhancing lesion in the posterior chamber of the left eye globe, reaching up to the posterior surface of the lens (white arrow). (F) Diffusion-weighted MRI in the axial plane demonstrates diffusion restriction in the lesion which suggesting hypercellularity of the lesion (white arrow).

demonstrated no abnormalities in the anterior segment. Fundus examination displayed vitreous haemorrhage, candle-wax spots and enlarged tortuous vessels. B-scan ultrasonography showed irregular ill-defined hypoechoic lesions located in the posterior chamber with multiple low-level echoes. Intraocular pressure was $14 \mathrm{~mm} \mathrm{Hg}$ in both eyes. Visual acuity and examination of the right eye

\section{Patient's perspective}

I was distressed to see my daughter in pain and sudden vision loss and seeing her in such a lifethreatening situation. We came to the hospital with great hopes of saving her life. Doctors assured us about the condition of the patients and made us understand that the left eye is in grave condition and we are supposed to remove it to save the baby's life. After lots of discussions, we agreed to remove the left eye. Though it is quite traumatic to see her with a single eye, we are happy doctors could save my daughter's life. Doctors also asked us to come for a general check-up every month. 


\section{Learning points}

The posterior chamber lesion may be masked under the direct ophthalmoscopic examination due to a significant amount of vitreal haemorrhage.

- Radiological examination plays an imperative role in the diagnosis of retinoblastoma as it guides us on the lesion characteristic and extension.

- MRI orbit is the ideal investigation for retinoblastoma because of its inherent high soft-tissue resolution and to rule out the extension of the disease in the subarachnoid space via the optic nerve.

were normal. Routine investigation of bone marrow, cerebrospinal fluid and blood was unremarkable.

MRI scan with contrast of the brain and orbit was performed for further evaluation, which elicited abnormal high-intensity signals in the left eye globe on T1 images, differential fluid signal intensities forming fluid-fluid, levelling on T2-weighted images, along with a heterointense lesion in the posterior chamber. Susceptibility-weighted images showed blooming in the lesion suggestive of calcification. Diffusion-weighted images demonstrate restricted diffusion suggesting the hypercellularity of the lesion. The postcontrast study revealed an enhancing, irregular intraocular mass within the posterior chamber of the left globe. The optic nerve head did not demonstrate abnormal enhancement. No definitive evidence of the left optic nerve involvement or intracranial extension was seen on the MRI scan (Figure 1A-F). The right eye globe was normal.

Contributors RC and TT contributed to the planning, conduct, reporting, conception and design, acquisition of data or analysis and interpretation of data. RS and SG contributed to the acquisition of data and interpretation of data.

Funding The authors have not declared a specific grant for this research from any funding agency in the public, commercial or not-for-profit sectors.

Competing interests None declared.

Patient consent for publication Consent obtained from parent(s)/guardian(s).

Provenance and peer review Not commissioned; externally peer reviewed.

\section{ORCID iD}

Rajaram Sharma http://orcid.org/0000-0003-1126-5875

\section{REFERENCES}

1 Amoaku WM, Willshaw HE, Parkes SE, et al. Trilateral retinoblastoma. A report of five patients. Cancer 1996;78:858-63.

2 Young JL, Smith MA, Roffers SD. Retinoblastoma. In: Reis LAG, Smith MA, Gurney JG, eds. Cancer incidence and sur-vival among children and adolescents: United States SEER program 1975-1995. Bethesda, MD: National Institutes of Health, 1999.

3 Blach LE, McCormick B, Abramson DH, et al. Trilateral retinoblastoma--incidence and outcome: a decade of experience. Int J Radiat Oncol Biol Phys 1994;29:729-33.

4 De Potter P, Shields CL, Shields JA. Clinical variations of trilateral retinoblastoma: a report of 13 cases. J Pediatr Ophthalmol Strabismus 1994;31:26-31.

5 Provenzale JM, Gururangan S, Klintworth G. Trilateral retinoblastoma: clinical and radiologic progression. AJR Am J Roentgenol 2004;183:505-11.

6 Towbin RB, Bisset GS. Pediatric case of the day. trilateral retinoblastoma. Radiographics 1986;6:1100-4.

7 Smirniotopoulos JG, Bargallo N, Mafee MF. Differential diagnosis of leukokoria: radiologic-pathologic correlation. Radiographics 1994;14:1059-79.

Copyright 2021 BMJ Publishing Group. All rights reserved. For permission to reuse any of this content visit

https://www.bmj.com/company/products-services/rights-and-licensing/permissions/

BMJ Case Report Fellows may re-use this article for personal use and teaching without any further permission.

Become a Fellow of BMJ Case Reports today and you can:

- Submit as many cases as you like

- Enjoy fast sympathetic peer review and rapid publication of accepted articles

- Access all the published articles

- Re-use any of the published material for personal use and teaching without further permission

\section{Customer Service}

If you have any further queries about your subscription, please contact our customer services team on +44 (0) 2071111105 or via email at support@bmj.com.

Visit casereports.bmj.com for more articles like this and to become a Fellow 